\title{
ANDRÉ LUÍS GOMES ENTREVISTA JOHN GLEDSON
}

ANDRÉ: O historiador Nicolau Sevcenko afirma, em texto de apresentação de seu livro, que "Ficção e História proclama, com rigor categórico, quanto à obra de Machado de Assis é atual, quanto é oportuna e quanto sua leitura é não apenas uma iluminação inspiradora, mas sobretudo um imperativo da consciência ética para os cidadãos deste país". Cito a afirmação do historiador para incitar a leitura do livro e para lhe pedir que comente, de forma sucinta, o quanto é atual a obra machadiana.

JOHN GLEDSON: Bem, pode-se afirmar de muitas maneiras a atualidade de uma obra literária. Uma delas é mencionar o (para mim) inesperado sucesso da antologia dos contos que publiquei recentemente, pela Companhia das Letras, que está na sua terceira reimpressão. Isso prova duas coisas, para mim - que, quando publicado em edições cuidadas e convidativas Machado tem, ou pode ter, uma popularidade que vai além da escola e da academia. Nesse livro comentado pelo Nicolau, focalizei as idéias machadianas acerca da história do Brasil no século XIX, mas muitos (como o próprio Nicolau) têm visto que essas idéias, pela sua coerência intelectual e por se concretizarem em romances e contos que ainda se lêem com prazer e admiração, se impõem, e servem para interpretar muitos aspectos da sociedade e da história brasileira do século XX também. 
ANDRÉ: Após cem anos da morte de Machado de Assis, faz-se necessário procurar Por um novo Machado de Assis ${ }^{1}$ ?

JOHN GLEDSON: Acredito que sim. A visão que temos de Machado mudou radicalmente ao longo desses cem anos, e certas posições, por exemplo, dos críticos e biógrafos que escreveram sobre Machado, agora nos parecem ingênuos ou até inexplicáveis. Talvez a contínua renovação dos estudos sobre Machado se deva a uma coisa, sobretudo, - à sua ironia, que faz com que se perde muita coisa dita nas entrelinhas. Veja bem que só em 1960, com o livro de Helen Caldwell, fez-se totalmente pública uma chave da obra que é a (possível) inocência de Capitu - digo da obra inteira, não de Dom Casmurro somente. O que é mais, Machado sabia, ou intuía, que só depois de passados alguns anos sairiam a luz alguns segredos. Um exemplo - o feminismo, para mim claríssimo, mas tão escondido, por razões de realismo literário até, que muita gente não percebeu. Um apontamento importante: como disse no meu livro, esse novo Machado não o inventamos, ele está aí à nossa espera.

ANDRÉ: Vários críticos apontam mudanças repentinas na obra machadiana. Há, de fato, essas mudanças repentinas? Se há, o que explicaria esse o caráter "repentino" dessas mudanças?

JOHN GLEDSON: Uma mudança repentina há, é a que todo mundo conhece, a chamada "crise dos quarenta anos", a mudança enorme de Iaiá Garcia (1877) para Brás Cubas (1880-81). Neste caso, as explicações são múltiplas (biográficas e literárias principalmente, a doença que o forçou a recuperar-se em Nova Friburgo, a leitura de Sterne e outros). Talvez até a concentração nos romances tem obscurecido alguns aspectos dessa mudança - para mim, ambos enfatizam demais aspectos passivos. Quem nos deu uma explicação mais convincente porque radicada na experiência literária de Machado nos anos 70 é Roberto Schwarz, em Ao vencedor as batatas - no fundo, explica a mudança pela impossibilidade de dar conta da realidade social brasileira em seus aspectos mais profundos e... humilhantes, na forma "romântica" (simplificando) do romance. Cabe progredir

1 GLEDSON, JOHN. Por um novo Machado de Assis - ensaios. São Paulo: Companhia das Letras, 2006, 452p. 
mais no caminho que o Roberto nos mostrou nesse livro fundamental - em alguns contas, nas crônicas dos anos 70, sobretudo da segunda metade da década, vê-se que Machado não era nada passivo - sabia o que fazia, avaliou a sua situação como escritor, e reagiu com muita inteligência, tino, e principalmente, principalmente ousadia.

ANDRÉ: Em seus ensaios, o senhor afirma que alguns textos machadianos apresentam uma reflexão sobre identidade nacional. Pode-se afirmar que as reflexões machadianas contribuíram para a formação e/ou alteração dessa identidade? Em que medida?

JOHN GLEDSON: Duvido que tenham afetado muito essa identidade ou a noção que se tem dela, em grande parte porque são, ou eram, pouco conhecidas essas reflexões - andam escondidas nas entrelinhas de romances como Quincas Borba, ou contos como "O espelho", sempre visto como reflexão sobre a identidade humana (que também é). Machado tinha idéias originais sobre a identidade brasileira, por exemplo, achava que uma das desvantagens do país era justamente o tamanho, que tantos escritores acham uma glória nacional - temia a desintegração do país. Como as suas opiniões eram céticas e pouco convencionais, vale a pena conhecê-las, mas o mito do absenteísmo político, o "tédio à controvérsia", impediu que se conhecessem e se divulgassem [sic].

ANDRÉ: Em que medida, nas crônicas machadianas, a voz narrativa pode ser identificada com o escritor Machado de Assis?

JOHN GLEDSON: Na verdade, depende de qual série você está falando, pois as séries tinham todas uma personalidade, uma posição, uma situação próprias. Mas nas séries que conheço melhor, que são as "Notas semanais", de 1878, "Bons dias!", de 1888-89, e "A Semana" (1892-97), sempre achei útil supor que atrás da ironia, sempre em primeiro plano, esconde-se, às vezes, nem tão distante da superfície, a voz do autor, as opiniões do autor. Pode ser a ilusão de um crítico que sempre se interessou pela pessoa do autor, de Joaquim Maria Machado de Assis, mas acho que não - n' "A Semana”, por exemplo, todo mundo sabia que ele escrevia essas crônicas, ele se refere a momentos da vida dele (um primeiro encontro com a Carolina, em 1867, se não me engano, as conversas com Alencar na Livraria Garnier), e seria 
lógico supor que os demais pertenciam a ele. Em “Bons Dias!", a situação é outra, foram crônicas realmente anônimas, mas justamente ele usava (essa é minha posição, argumentada com detalhes num capítulo do meu livro), esse anonimato para exprimir opiniões que iam contra a corrente. Nas séries anteriores, tenho a impressão que a situação era ligeiramente diferente, na medida em que não se afirmara tanto com autor, e essas crônicas eram mais convencionais. Mas bem pode ser que me engane. Machado não nos deixou um diário, nem nada que se parecesse com diário - essas crônicas estão longe de o ser, é claro, mas são úteis para ver o autor no corpo-a-corpo com os acontecimentos.

ANDRÉ: Joel Pontes, em Machado de Assis e o Teatro, chama-nos a atenção para o espaço de tempo que o teatro ocupa na vida literária de Machado de Assis, seja como comediógrafo ou crítico teatral. Assim, como as publicações em jornais e revistas, o teatro explica algumas características das narrativas machadianas?

JOHN GLEDSON: Difícil responder, sem um conhecimento e um estudo maior que os meus. Mas Machado não seria uma exceção no século XIX, em que teatro era o modo mais imediato de comunicar com um auditório. O próprio Machado refere-se, em uma crônica que eu e a Lúcia Granja acabamos de editar, aos fracassos no teatro de Balzac e Alencar. $\mathrm{O}$ caso de Henry James, com um fracasso teatral que mudou a vida dele, em 1895 (com a peça Guy Domville) é outro caso. Ficção e teatro não são a mesma coisa, e Machado, depois das suas atividades teatrais nos anos 60, só de vez em quando, e como atividade ancilar ou ocasional, aventurou-se no teatro. A ironia, outra coisa no teatro que na prosa, deve ser uma das razões. Mas estou especulando, sem muita base fatual ou estilística.

ANDRÉ: Fazem parte da fortuna crítica de Machado de Assis alguns estudos realizados por estrangeiros como o de Helen Caldwell, The Brazilian Othello of Machado de Assis ${ }^{2}$, Dispersos de Machado de Assis e A juventude

2 Publicado por uma editora universitária norte-americana em 1960, foi traduzido para o português e publicado pela Editora Ateliê em 2002. Neste livro, Helen Caldwell argumenta pela primeira vez que Capitu, personagem do romance "Dom Casmurro", de Machado de Assis, é inocente do adultério que Bentinho lhe imputa. CALDWELL, Helen. Otelo de Machado de Assis. 
de Machado de Assis, do professor francês Jean-Michel Massa e os seus, Machado de Assis: Impostura e realism e Machado de Assis: Ficção e História, que mudaram o modo de pensar a obra machadiana no Brasil. Qual o impacto desses estudos fora do Brasil? Como o senhor avalia a recepção da obra de Machado de Assis fora do Brasil?

JOHN GLEDSON: Na verdade, esses estrangeiros tiveram impacto no Brasil, e não fora do Brasil - é uma generalização, mas nem tão injustificada assim. Isso porque a própria obra de Machado tem pouca repercussão fora do Brasil. Por isso, você vê, a tese do Massa, que tenho aqui em francês, dádiva do autor, nunca foi publicado como livro, meu primeiro livro, sobre Dom Casmurro, não teve efeito nenhum até ser traduzido para o português, e publiquei meus dois livros seguintes só em português. A exceção talvez seja a Caldwell, cujo livro sobre Dom Casmurro, que você cita, só foi publicado em português recentemente, muitos anos depois de sua publicação em inglês. Mas sua repercussão limitou-se aos círculos acadêmicos. A questão interessante é o efeito (considerável, tenho a impressão), que esses estrangeiros tiveram no Brasil. 